\title{
Cancer incidence and mortality among Swedish smelter workers
}

\author{
ANITA I M SANDSTRÖM,' S G I WALL, ' A TAUBE ${ }^{2}$ \\ From the Department of Epidemiology and Health Care Research, ${ }^{\prime}$ University of Umeå, S-901 85 Umeå, and \\ Department of Statistics, ${ }^{2}$ Uppsala University, S-751 20 Uppsala, Sweden
}

ABSTRACT Cancer incidence was analysed in a retrospective cohort of 3710 male Swedish smelter
workers between 1958 and 1982 using a record linkage with the Swedish Cancer Register. During this
period 467 cancers were registered in the cohort. An excess incidence of total cancer of about $30 \%$ was
shown relative to general and local populations mainly due to 120 respiratory cancers. Excess SMRs
for all cancer and respiratory cancer were highly significant. Trends in the incidence of cancer were
studied using moving five year calendar periods. A decreasing rate of lung cancer was found during
$1976-80$ for both mortality and incidence. Incidence figures for two more years show a continued
decreasing trend. This is validated by an analysis of different employment cohorts, taking latency into
account, showing that the later the date of first employment the lower the incidence of cancer,
especially for lung cancer.

Rönnskärsverken is a copper smelter in north eastern Sweden, established in 1928 to process ore from the Boliden mine. The ore is highly complex, being composed not only of metallurgic concentrates of copper, lead, zinc, gold, and silver but also of such contaminants as sulphur, cadmium, arsenic, and mercury. Owing to its high arsenic content, the ore initially had to be transported to a special smelter in the United States. In order to expand, however, it was soon realised that a special smelter was needed close to the mine. A partially new smelting process was designed and constructed at Rönnskär and production started in 1930. The unrefined ore was delivered by rail from the mine to the smelter where, after being crushed, it was roasted to drive off the arsenic and most of the sulphur in the form of gas. This gas was then cooled and purified, the crude arsenic trioxide being precipitated and the sulphur dioxide emitted to the atmosphere. A reverberatory furnace then smelted the calcine and the slag was drawn off into tubs and dumped into the sea. The resulting material, consisting of copper and iron sulphides, was poured into a converter where the sulphur was removed by means of oxidation to sulphur dioxide. Initially, copper was the main product but, since the ore was not refined, large quantities of arsenic and sulphur were also derived. The arsenic content in particular soon became a central problem. Until 1931, arsenic was mixed with

Accepted 18 January 1988 cement to make concrete blocks which were sunk ingtoce the Gulf of Bothnia. Thereafter the crude arsenic wi stockpiled. After some years, however, the process wâs, developed further to refine crude arsenic into saleate products.

Workers employed at Rönnskärsverken have been subject to medical examination since the 1930 s. Visible health problems were then dominated by gas and $\overrightarrow{\overrightarrow{0}}$ etching injuries. In 1932 sick leave was reported for $9 \%$ of the working days due to these problems and certain departments showed figures as high as 20 $30 \%$. Sjöstrand found that subjective respiratory problems and reduction of physical work capacity? were reported mainly among workers at the roasting furnace, the reverberatory furnace, and at the conver- ter aisle.'

Chronic changes in the respiratory organs, often with signs of atrophy of the mucous membranes, were윽 also verified. These findings were labelled "the Rönn- $>$ skär disease," the medical and $x$ ray picture of which were later described in several reports. ${ }^{2-4}$ Holmqvist related occupational dermatosis to exposure to arsen- $-{ }^{-1}$ ic $^{5}$ and, in a subsequent case-control study by Axelsson $N$ et al exposure to arsenic was also associated with an excess lung cancer mortality. ${ }^{6}$

In 1975 the Swedish government ultimately initiated further investigations of the smelter environment. Since then some 50-60 different environmental studies $\stackrel{\oplus}{?}$ on the smelter surroundings (animals, air, water, 0 vegetation, and population) have been made as well as 
on the workers themselves (perceived health, mortality, life expectancy, reproduction).

When comparing lung cancer mortality close to the smelter with a reference area, Pershagen et al found significant excess risks which did not remain, once the occupationally exposed were excluded. ${ }^{7}$ In a later casecontrol study it was statistically verified, however, that excess risks of lung cancer still prevailed after accounting for smoking and job history. ${ }^{8}$

A study of the survival and mortality patterns among the workers was initiated in 1976 by the labour union and the health care unit at Rönnskärsverken.' This retrospective cohort study showed that there was a general excess mortality among the Rönnskär workers when compared with local male populations and Swedish men in general. As a consequence, survival among the workers in the 1960s and 1970s was reduced to about the same level as that of Swedish men in the 1930s and 1940s. The overall excess mortality was due both to cancer and to circulatory diseases. The roaster departments presented the most hazardous exposure with regard to cancer, especially lung cancer.

In a subsequent case-control study of lung cancer within the cohort simultaneous analysis of roaster exposure and smoking showed that the two factors acted according to a multiplicative model rather than an additive one. ${ }^{11}$ The analysis found 61 "aetiological" cases of lung cancer out of 76 that "would not have occurred had the persons in question not been smokers and/or not worked at the roaster departments." A further analysis indicated that the roaster exposure involved "arsenic exposure."

Previous studies have included only mortality data for the period up to $1977 . .^{911}$ The aim of the present study was to analyse cancer morbidity in terms of incidence for the same cohort of workers as in the retrospective mortality study, now updated to 1 January 1983.

\section{Materials and methods}

The cohort included all male workers first employed at Rönnskärsverken from its beginnings in 1928 and before 1967 for total periods of at least three months. The analysis was made possible by using the Swedish Cancer Register, which contains all new cases of cancer diagnosed from 1958 onwards. Thus the study cohort is defined here as those of the original cohort alive at this date or first employed thereafter but before 1 January 1967. This comprised a total of 3710 workers.

Data on work history were gathered from employment records. The individual exposure was a combination of duration of exposure at each worksite and calendar time. The available historical information made it possible to follow up each worker from his first employment through different jobs at Rönn- skärsverken. By means of the individual civic code system established in Sweden in 1947, each worker could be traced in the Swedish Cause of Death Register and in the Swedish Cancer Register. Data from the Regional Cancer Register for the years 1983-4 were used to estimate the incidence of cancer among Rönnskär workers for these years by making the assumption that migration out of the region was similar to that in previous years. Comparisons were also made using directly standardised rate ratios (SRR). Moving calendar periods were used to study time trends within the cohort. The risk population for the analysis of the incidence of cancer was defined by the person-time distribution of follow up from first employment (or 1 January 1958, for individuals employed before 1958) to the study end point or prior death. When analysing lung and stomach cancer, person-time is accumulated to the diagnosis of lung cancer or death. For the study of all cancer or site categories, diagnosis of cancer will not qualify for withdrawal. This follow up has resulted in a total lived through risk time of 79319 person-years (which was about 300 person-years more than for the analysis of lung cancer).

For external comparisons the expected number of cases of cancer was calculated using age and calendar time specific incidence rates for the general Swedish male population and for the male populations of Västerbotten county and of Skellefteå municipality (Rönnskärsverken is in Skellefteå municipality in Västerbotten county.) The corresponding incidence rates were applied to the observed person-time experience of the entire cohort. Internal comparisons were made specifically to validate previous findings on hazardous worksites and to judge whether excess risks still prevail for those later employed. When analysing specific worksites, person-years were accumulated from first employment at the actual worksite.

Here the importance of time will be illustrated in terms of latency (from first employment), exposure (duration of employment), and calendar time (year of first employment).

Diagnoses of cancer were coded according to the International Classification of Diseases (ICD-7) and the analysis was concentrated on all cancers, cancer of the digestive tract (stomach in particular), respiratory cancer (mainly lung), cancer of the urogenital organs and of the blood, bone marrow, and lymphatic system. Other site categories did not permit specific analysis because of small numbers.

\section{Results}

Between 1958 and 1982, a total of 467 diagnoses of cancer was registered in the Swedish Cancer Register, of which 33 had more than one cancer. Table 1 shows classification of cases by age and site categories. Half the cases occurred before 1970 . 
Table 1 Number of cancer cases 1958-82 among 3710 workers by age and cancer site

\begin{tabular}{|c|c|c|c|c|c|}
\hline \multirow[b]{2}{*}{$I C D-7$} & \multirow[b]{2}{*}{ Site } & \multicolumn{3}{|c|}{ Age groups (y) } & \multirow[b]{2}{*}{ All ages } \\
\hline & & $15-44$ & $45-64$ & $\geqslant 65$ & \\
\hline $\begin{array}{l}140-149 \\
150-159 \\
151 \\
160-164 \\
162 \\
177-181 \\
200-209 \\
190-199\end{array}$ & $\begin{array}{l}\text { Lip, oral cavity, and pharynx } \\
\text { Digestive organs } \\
\text { Stomach } \\
\text { Respiratory organs } \\
\text { Trachea, bronchus, lung and pleura, primary } \\
\text { Urogenital organs } \\
\text { Blood, bone marrow, lymphatic system } \\
\text { Others and unspecified }\end{array}$ & $\begin{array}{l}0 \\
3 \\
1 \\
3 \\
2 \\
4 \\
2 \\
3\end{array}$ & $\begin{array}{r}2 \\
49 \\
27 \\
57 \\
50 \\
39 \\
17 \\
24\end{array}$ & $\begin{array}{r}5 \\
78 \\
25 \\
60 \\
56 \\
81 \\
17 \\
23\end{array}$ & $\begin{array}{r}7 \\
130 \\
53 \\
120 \\
108 \\
124 \\
36 \\
50\end{array}$ \\
\hline $140-209$ & All sites & 15 & 188 & 264 & 467 \\
\hline
\end{tabular}

\section{INCIDENCE OF CANCER IN REFERENCE \\ POPULATIONS}

In terms of directly standardised incidence rate ratios (SRR) a comparison was made between the three reference populations (table 2). The greatest differences were found for lung and stomach cancer. Rates of stomach cancer for both Skellefteå and Västerbotten were much higher than the rate for Sweden. ${ }^{12}$ For lung cancer, however, the rate for Västerbotten was much lower than the rates for Sweden and Skellefteå. In Skellefteå 290 cases of lung cancer occurred during 1959-82, whereas the corresponding figure for the Rönnskär cohort was 105 . This was probably the major reason why the rate for Skelleftea was more similar to that of Sweden than to that of its own county, Västerbotten, and indicates that the incidence of lung cancer in the male population in Skelleftea municipality was highly affected by the incidence among Rönnskär workers.

\section{EXTERNAL COMPARISONS}

When comparing the incidence of cancer among Rönnskär workers with general and local populations, in terms of standardised morbidity ratios and accounting for age and calendar time (table 3), a 24-34\% excess of the incidence of total cancer was found. This was mainly due to the 120 respiratory cancers, $70-85$ more cases than would be expected from reference figures.

Excess SMR values for all cancer and respiratory $\stackrel{\circ}{\circ}$ cancer were significant, whichever reference popula- $N$ tion was used (fig 1). Excluding respiratory cancer $N$ from the all cancer category resulted in a SMR value of $\stackrel{\circ}{\longrightarrow}$ 111 compared with Swedish men, which was barely significant. Respiratory cancer was almost synon- $\overparen{T}$ ymous with lung cancer (108 of 120 cases). Owing을 mainly to stomach cancer, the observed excess figure for digestive cancer was eliminated when comparing with local populations.

Trends in the incidence pattern of cancer duriege 1958-82 for Rönnskär workers were compared wi those of Swedish men (fig 2). Starting from an almest equal level in the early 1960s, a significantly increasing trend was shown for Rönnskär workers towards the mid-1970s followed by a levelling off thereafter.

For lung cancer (fig 3), a similar pattern was also evident. Using moving five year calendar periods (1958-62, 1959-63 and so on), a decreasing rate of lung cancer was shown from the late 1970 s for both? mortality and incidence. For $1979-83$ and 1980-4, incidence figures were estimated using the regional cancer register showing a continued decreasing trend. 3

In terms of SMRs (fig 4), the threefold or fourfold increase relative to general and local populations

Table 2 Comparison between the three reference populations in terms of directly standardised rate ratios (SRR)

\begin{tabular}{|c|c|c|c|c|}
\hline$I C D-7$ & Site & Sweden & $\begin{array}{l}\text { Västerbotten } \\
\text { county }\end{array}$ & $\begin{array}{l}\text { Skellefted } \\
\text { municipality }\end{array}$ \\
\hline $\begin{array}{l}150-159 \\
151 \\
153-154 \\
162 \\
177-181 \\
177 \\
180 \\
181 \\
200-209\end{array}$ & $\begin{array}{l}\text { Digestive organs } \\
\text { Stomach } \\
\text { Colon and rectum } \\
\text { Trachea, bronchus, and pleura, primary } \\
\text { Urogenital organs } \\
\text { Prostate } \\
\text { Kidney } \\
\text { Urinary organs (excluding kidney) } \\
\text { Blood, bone marrow, and lymphatic system }\end{array}$ & $\begin{array}{l}100 \\
100 \\
100 \\
100 \\
100 \\
100 \\
100 \\
100 \\
100\end{array}$ & $\begin{array}{r}102 \\
136 \\
87 \\
71 \\
98 \\
102 \\
101 \\
90 \\
111\end{array}$ & $\begin{array}{r}106 \\
130 \\
89 \\
95 \\
93 \\
87 \\
114 \\
98 \\
123\end{array}$ \\
\hline $140-209$ & All sites & 100 & 94 & 100 \\
\hline
\end{tabular}


Cancer incidence and mortality among Swedish smelter workers

Table 3 Age and site specific cancer incidence among Rönnskär workers in terms expected number of cases and standard morbidity ratios relative to three different reference populations. ( $S M R=100$ for reference populations)

\begin{tabular}{|c|c|c|c|c|c|c|c|c|c|}
\hline \multirow[b]{3}{*}{$\begin{array}{l}\text { ICD } \\
\text { code }\end{array}$} & \multirow[b]{3}{*}{ Site } & \multirow[b]{3}{*}{ Age } & \multirow[b]{3}{*}{$\begin{array}{l}\text { Obs } \\
\text { cases }\end{array}$} & \multicolumn{6}{|c|}{ Reference populations } \\
\hline & & & & \multicolumn{2}{|c|}{ Sweden } & \multicolumn{2}{|c|}{ Västerbotten } & \multicolumn{2}{|c|}{ Skellefted } \\
\hline & & & & $\begin{array}{l}\text { Exp } \\
\text { cases }\end{array}$ & $\begin{array}{l}S M R \\
(\%)\end{array}$ & $\begin{array}{l}\text { Exp } \\
\text { cases }\end{array}$ & $\begin{array}{l}S M R \\
(\%)\end{array}$ & $\begin{array}{l}\text { Exp } \\
\text { cases }\end{array}$ & $\begin{array}{l}S M R \\
(\%)\end{array}$ \\
\hline \multirow[t]{2}{*}{$150-159$} & Digestive organs & $\begin{array}{l}15-44 \\
45-64 \\
65-\end{array}$ & $\begin{array}{r}3 \\
49 \\
78\end{array}$ & $\begin{array}{r}3 \cdot 3 \\
47 \cdot 7 \\
60 \cdot 4\end{array}$ & & $\begin{array}{r}3.7 \\
51.4 \\
62.7\end{array}$ & & $\begin{array}{r}3 \cdot 0 \\
51 \cdot 3 \\
63 \cdot 5\end{array}$ & \\
\hline & & $15-$ & 130 & $111 \cdot 4$ & 117 & $117 \cdot 8$ & 110 & $117 \cdot 8$ & 110 \\
\hline \multirow[t]{2}{*}{$160-164$} & Respiratory organs & $\begin{array}{l}15-44 \\
45-64 \\
65-\end{array}$ & $\begin{array}{r}3 \\
57 \\
60\end{array}$ & $\begin{array}{r}1.2 \\
24.9 \\
25.6\end{array}$ & & $\begin{array}{r}1.0 \\
16 \cdot 1 \\
18 \cdot 7\end{array}$ & & $\begin{array}{r}0.6 \\
22.6 \\
22.0\end{array}$ & \\
\hline & & $15-$ & 120 & $51 \cdot 7$ & 232 & $35 \cdot 8$ & 335 & $45 \cdot 2$ & 265 \\
\hline \multirow[t]{2}{*}{$177-181$} & Urogenital organs & $\begin{array}{l}15-44 \\
45-64 \\
65-\end{array}$ & $\begin{array}{r}4 \\
39 \\
81\end{array}$ & $\begin{array}{r}3 \cdot 2 \\
39 \cdot 3 \\
71 \cdot 3\end{array}$ & & $\begin{array}{r}2.6 \\
35 \cdot 4 \\
68 \cdot 2\end{array}$ & & $\begin{array}{r}2.5 \\
34.6 \\
54.9\end{array}$ & \\
\hline & & $15-$ & 124 & $113 \cdot 8$ & 109 & $106 \cdot 2$ & 117 & $92 \cdot 0$ & 135 \\
\hline \multirow[t]{3}{*}{$200-209$} & $\begin{array}{l}\text { Blood, bone marrow, lymphatic } \\
\text { system }\end{array}$ & $15-44$ & 2 & $2 \cdot 9$ & & $3 \cdot 3$ & & $4 \cdot 1$ & \\
\hline & & $\begin{array}{l}45-64 \\
65-\end{array}$ & $\begin{array}{l}17 \\
17\end{array}$ & $\begin{array}{l}15 \cdot 3 \\
14 \cdot 2\end{array}$ & & $\begin{array}{l}16 \cdot 7 \\
15 \cdot 9\end{array}$ & & $\begin{array}{l}17 \cdot 9 \\
15 \cdot 0\end{array}$ & \\
\hline & & $15-$ & 36 & $32 \cdot 4$ & 111 & 35.9 & 100 & 36.9 & 98 \\
\hline \multirow[t]{2}{*}{$140-209$} & All sites & $\begin{array}{l}15-44 \\
45-64 \\
65-\end{array}$ & $\begin{array}{r}15 \\
188 \\
264\end{array}$ & $\begin{array}{r}17 \cdot 1 \\
161 \cdot 1 \\
198 \cdot 5\end{array}$ & & $\begin{array}{r}16.3 \\
148.6 \\
185.9\end{array}$ & & $\begin{array}{r}15.2 \\
155.8 \\
177.3\end{array}$ & \\
\hline & & $15-$ & 467 & $376 \cdot 7$ & 124 & $350 \cdot 8$ & 133 & $348 \cdot 3$ & 134 \\
\hline
\end{tabular}

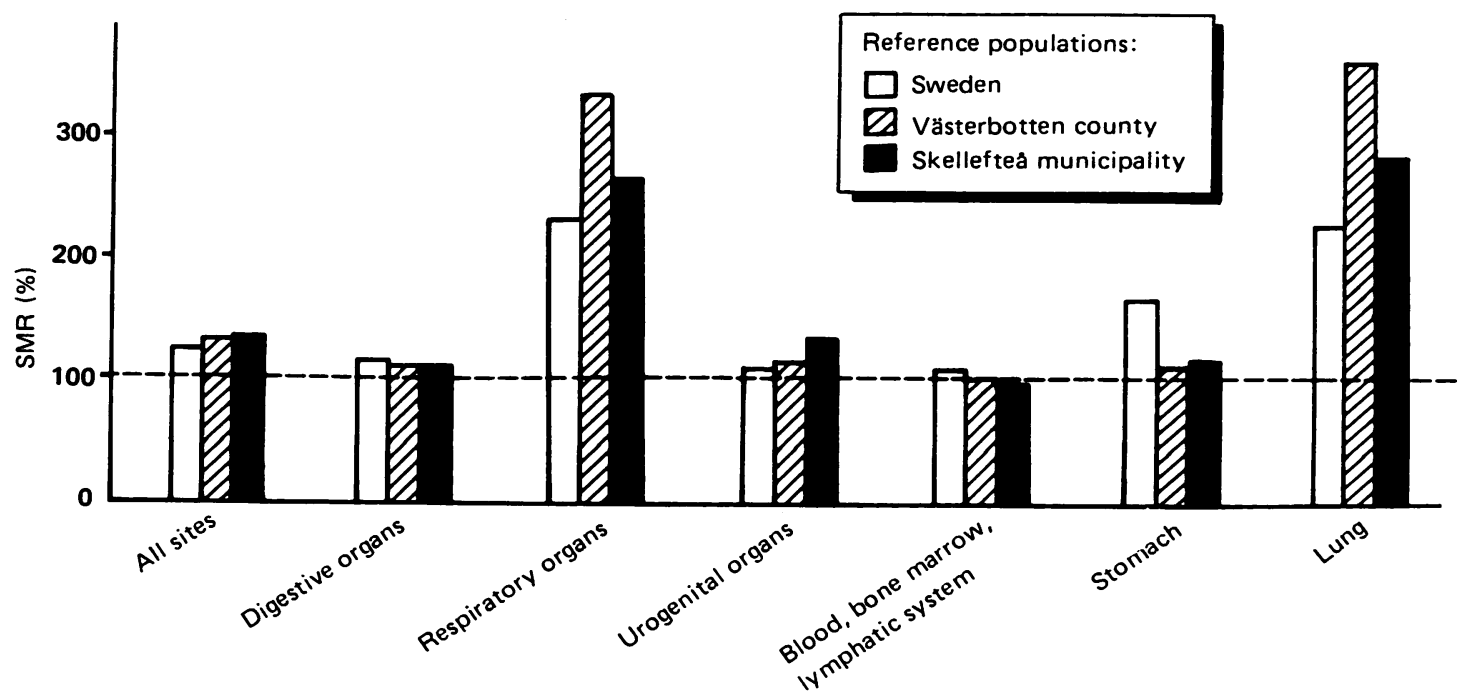

Fig 1 Incidence of cancer among Rönnskär workers in terms of standardised morbidity ratios (SMR $=100$ for reference populations) for different site categories. 

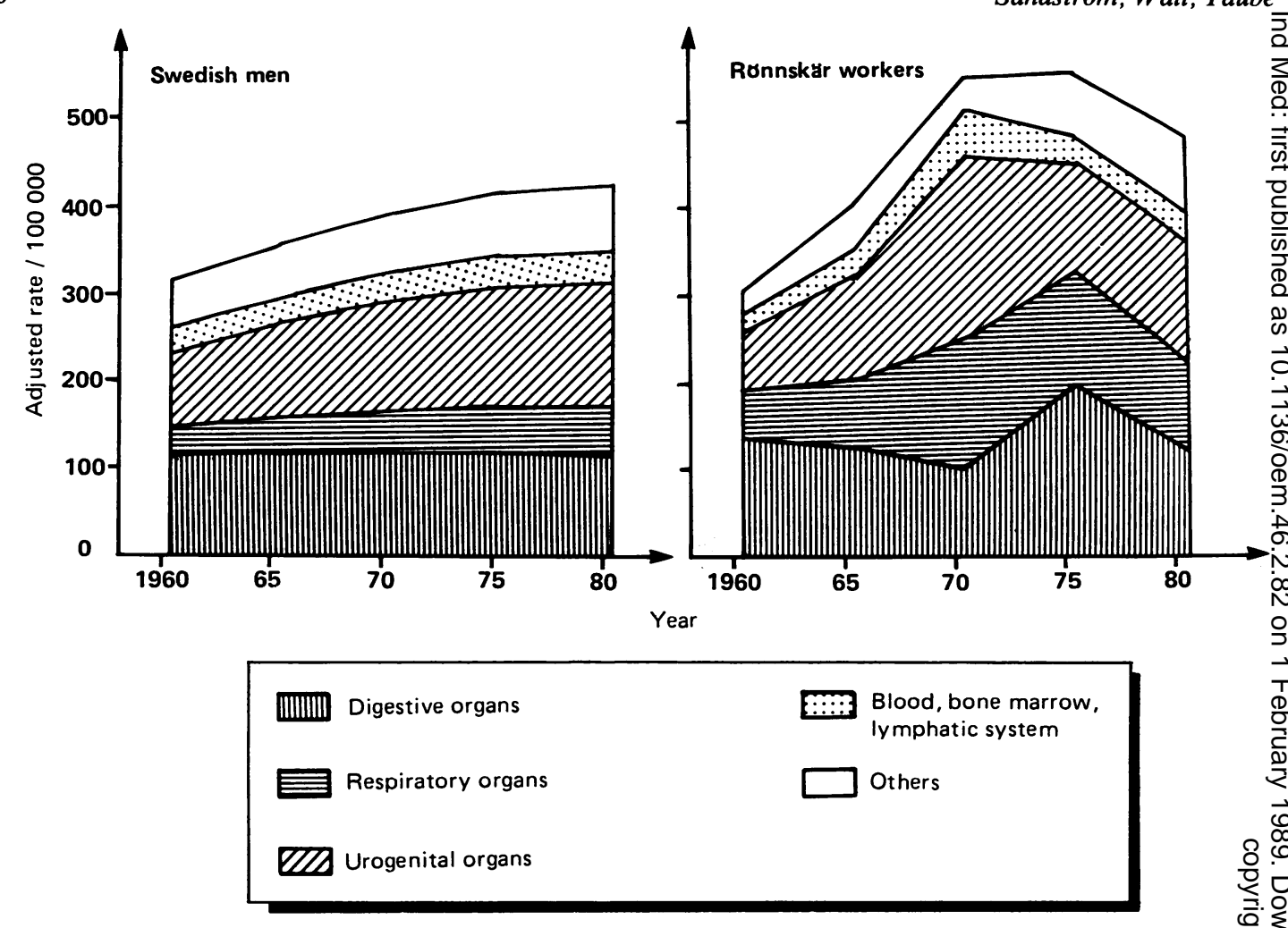

Fig 2 Cancer incidence pattern among Rönnskär workers and Swedish male population 1958-82. (Adjusted rates calculate $\frac{\bar{\partial}}{\overline{0}}$ using Swedish male population 1951-5 as a standard.)

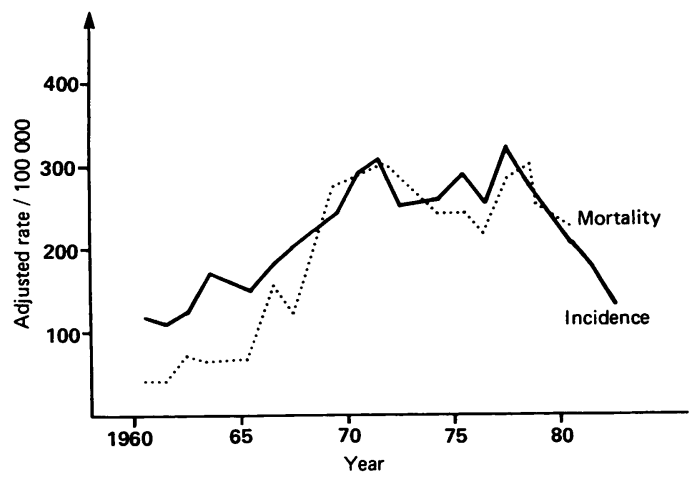

Fig 3 Incidence and mortality of lung cancer among Rönnskär workers. (Adjusted rates calculated using Swedish male population 1951-5 as a standard.) Rates are calculated using moving five year calendar periods. during the mid-1970s were followed by five successive decreasing values, down to 1.5 -fold and twofold respectively. Less attention to the values should be paid here for the municipality of Skellefteå in view of the impact of the cohort itself.

INTERNAL COMPARISONS

The effects of latency were expected to be small in this study as follow up did not start until 1958. Wheno therefore, a latency period of 15 years was used for external comparisons, the SMR value was 255 for lung. cancer instead of 234 without latency criteria.

Similarly, the effects of total exposure time werér estimated in terms of SRR for those employed less than five years and for those employed five years of more. Table 4 (including only the age range 45-64 toenable valid comparisons) shows that risk gradients were particularly evident for incidence of lung cancer.

The "exposure" of "total employment time" was not specified. Probably a "survivor population 


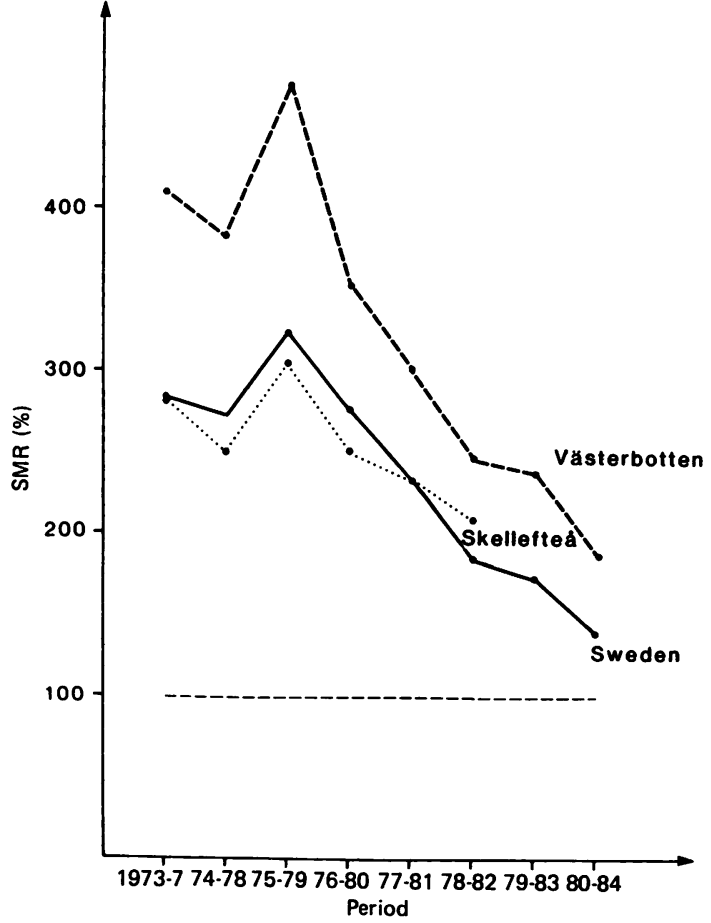

Fig 4 Incidence of lung cancer among Rönnskär workers relative to reference populations (SMR $=100)$ by five year moving calendar periods for 1973-84. (Figures for 1983 and 1984 are estimated using data from regional cancer register.)

Table 4 Site specific cancer incidence (ages 45-64) among Rönnskär workers for different total exposure times in terms of age standardised rates and rate ratios (SRR)

effect"13 also operated and job specific exposure time was therefore more relevant. Such an analysis confirmed the previous mortality analysis (table 5), with excess risks of lung cancer among roasters, arsenic workers, nickel smelters, and workers at the machine shop. When "eliminating" these sites SMR values of 172 remained for incidence and 140 for mortality relative to the Swedish male population.

If interpreted as the effects of a changing work environment the decreasing trends of lung cancer shown in figs 3 and 4 might partially be validated by an analysis of different employment cohorts. From fig 5 we see that the later the date of first employment, the lower the incidence of cancer (especially for lung cancer). For all cancer, the excess risk relative to the Swedish male population no longer prevailed for workers employed in 1945 or after. For lung cancer, however, 17 observed cases occurred in this cohort compared with 11.2 expected. In relation to local populations (8.0 and 9.8 expected cases) the excess risks were statistically significant, but not among those employed in 1950 or thereafter. Owing to varying latency periods, comparisons between different employment cohorts might not be easily interpreted. To improve validity in comparisons between employment cohorts, follow up was restricted to the range 15-33 years (fig 5). To some extent this increased the SMR for lung cancer among those later employed, but the overall pattern did not change.

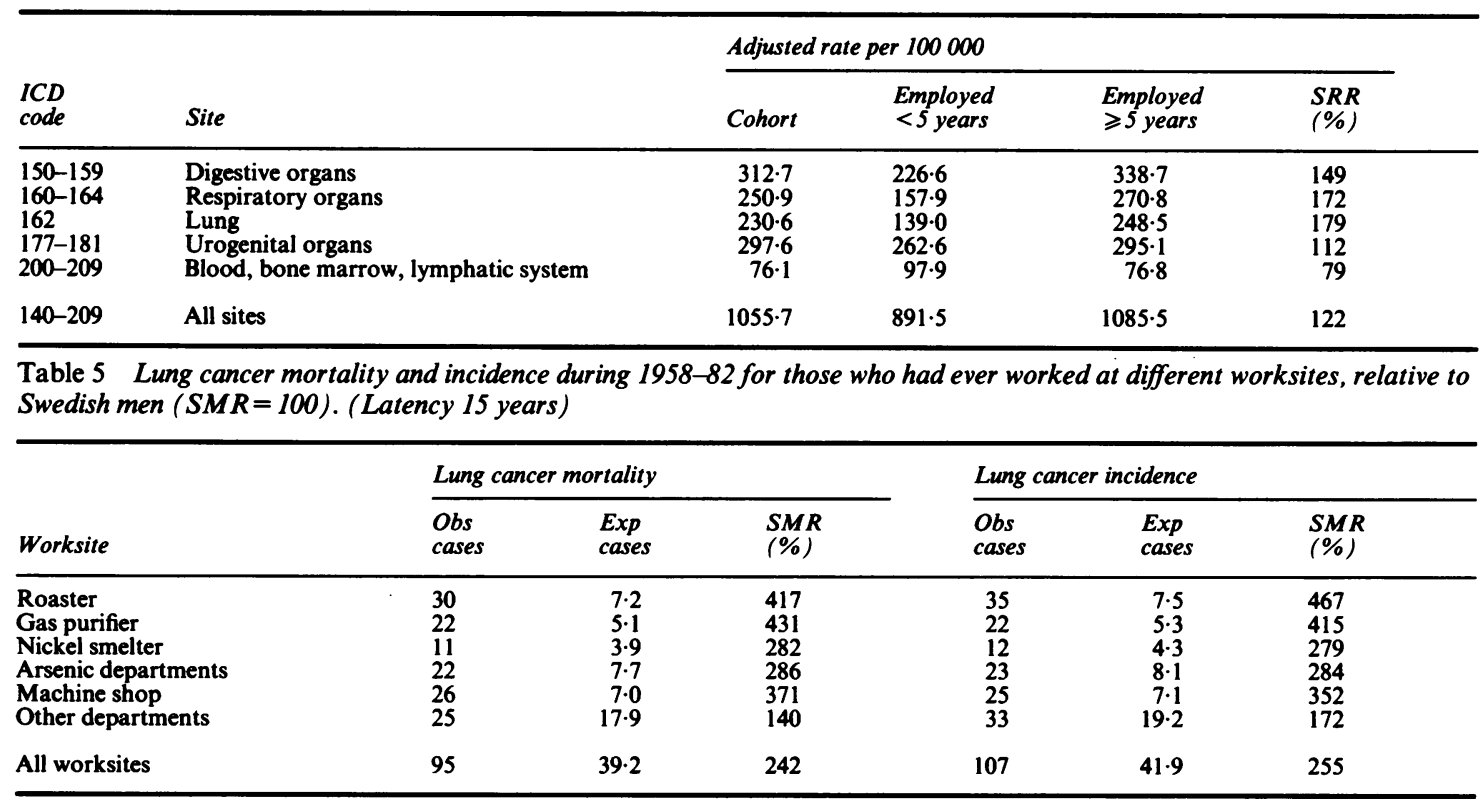




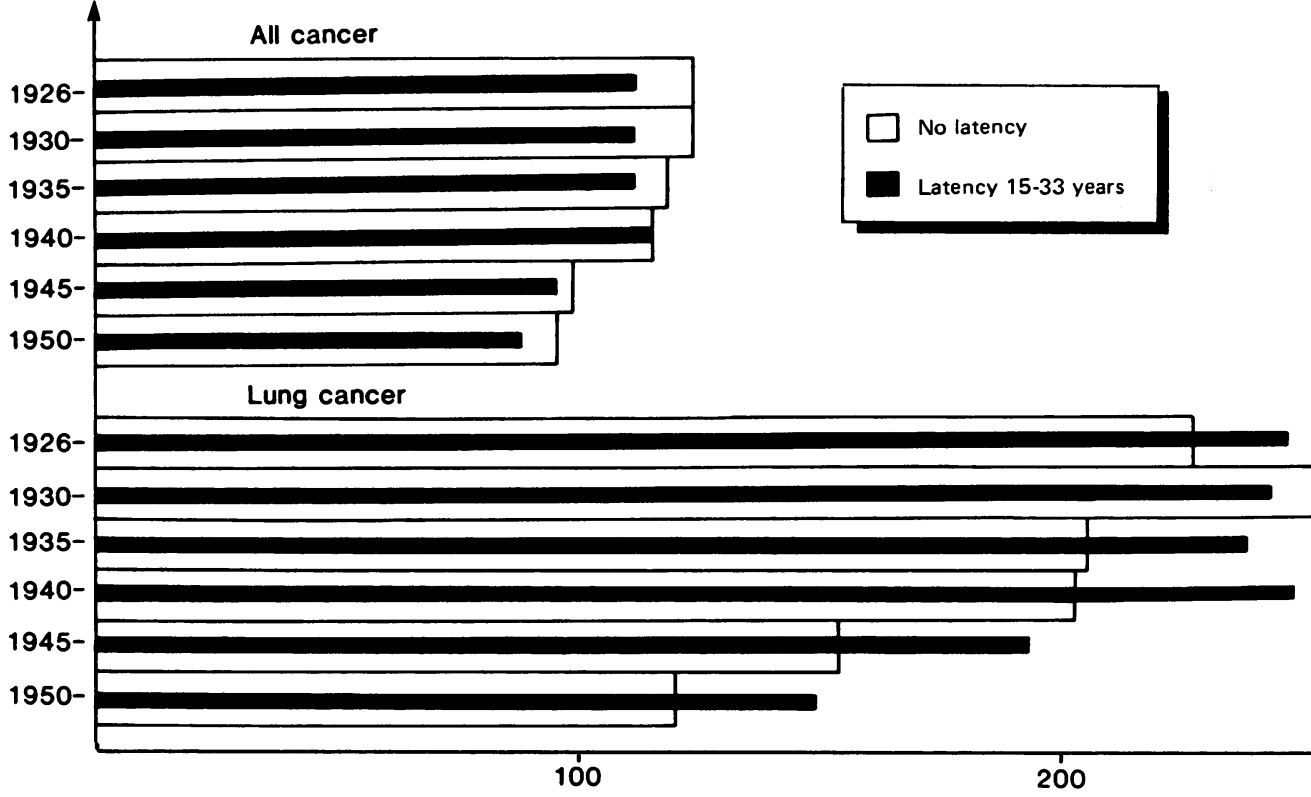

Fig 5 Incidence of cancer among Rönnskär workers by year of first employment for entire cohort and with latency 15-33 years, relative to Swedish men $(S M R=100)$.

\section{Discussion}

Previous mortality analyses showed excess risks among Rönnskär smelter workers, especially for lung cancer. " About one third of the workers accounted for most of these excess risks (roasters and arsenic workers, nickel smelters, and workers at the machine shop). These results were confirmed by the present analysis of the incidence of cancer, which also showed an encouraging decreasing trend of lung cancer in the cohort. The analysis of different employment cohorts also confirmed lowered risks for those later employed. Despite these positive developments, however, risks of lung cancer were not yet the same as those of the reference populations.

As might be expected, the differences between the cancer register and the cause of death register varied for different sites, due mostly to varying survival rates. Comparison of the incidence of cancer and cancer mortality were also complicated by their use of different systems of classification. A validation on an individual basis of cancer diagnosis at the death certificate and in the cancer register is under way.

The observed mortality and morbidity figures and the decreasing trends should, of course, be interpreted in view of early notifications of health problems and hazards and also consider technical and hygienic measures taken at the smelter. Changing smoking habits may also, in view of the smoking-arsenio synergism, ${ }^{10}$ have accelerated these trends.

The recruitment of workers was mainly from forestry and agriculture and from among unskilled workers. They were unaware of environmental problems and risks associated with modern industry and were used to breathing without fear.

In 1932 the first joint safety and health committee was appointed at Rönnskärsverken and an industrial physician and a safety engineer were also employed. Preventive work at the smelter was mainly directed towards the Rönnskär disease.

In view of the results of this study, it may also be warranted to analyse the changing environment of some of the risk locations within the smelter. ${ }^{14}$ The roaster departments including the gas purifier had an environment where most problems prevailed. The raw material was rich in arsenic, sulphur, and heavy metals. The process lacked ventilation, the handling of calcine was manual, and the work heavy. Trucks were introduced by the end of the 1930s, ventilation was gradually improved during the 1940 s, and in 1953 a new gas purification system was introduced. In 1975 a further improvement eliminated the previous transport of crude arsenic and since 1978 a vacuum system has been used. In 1978 overtime work at the roasters was forbidden by the safety committee. After having operated for almost 50 years, the roasters were 
replaced in 1980 by a single fluidised bed furnace since when the roasters have been operated mainly from the control room.

The nickel smelter was only in operation during the mid-1940s, causing great hygienic problems. Thus during January-February 1943, 13 workers were poisoned and one died. Fine grained nickel fume, infiltrating the protective masks, was released during the reduction process.

In arsenic departments workers at the arsenic refining and arsenic metal works were most exposed. During refinement, the raw arsenic is freed from pollutants such as sulphuric acid and heavy metals and arsenic trioxide powder is produced. This may also be further reduced into metallic arsenic. Originally, a dry refinement method was used, which caused many perforations of the nasal septum and etching injuries. After 1935, a wet method brought considerable improvement but unsatisfactory methods (dry, flotation, etc) remained in use until 1957. The packing of refined arsenic was unsatisfactory, however, until the present refinery was built in 1962 . Contents as high as $0.64 \mathrm{mg} / \mathrm{m}^{3}$ were recorded. A new arsenic metal plant was erected in 1972 and later rebuilt in 1976. Previously, the old plant had had an environment that forced workers to spend some two to three hours a day on hygienic measures.

Workers at the machine shop often had service functions throughout the smelter. Repair works inside the shop were sometimes associated with asbestos and other toxic materials. Furthermore, welding gases often contained chromium and nickel.

In view of the analyses of mortality and incidence of cancer and of the changes in the work environment we conclude that the large excess risk of lung cancer is due predominantly to the environmental conditions of the 1930 s and 1940s. This is also a consequence of the long latency periods preceding the occurrence of lung cancer. Improved technical and hygienic conditions at the smelter have obviously contributed to the positive declining trends in lung cancer relative to external populations. This is supported by the observations that excess risks among those employed after 1950 are less pronounced. This must, however, be interpreted taking latency into account. When comparing three employment cohorts (first employed before 1940, in the 1940s, and after 1950) and restricting follow up to between 15 and 33 years (to increase validity in comparisons) small numbers will make the analysis less stable. The pattern remains, however, that excess risks are mainly to be found among those earlier employed. The observed trends strongly motivate further follow up, especially of the incidence of cancer. Similarly, studies of other categories of workers at the plant-for example, the salaried employees-and of surrounding populations may provide further essential information. It is also mandatory that information on exposures for known and suspected agents are monitored and evaluated continuously. The observations made so far do not exempt working under calculated risks from further preventive actions or sanctions.

This study was financially supported by the Swedish Fund for Work, Environment and Protection and by the Cancer Fund at Umeå Regional Hospital.

\section{References}

1 Sjöstrand T. Changes in the respiratory organs of workmen at an ore smelting works. Acta Med Scand Suppl 1947;196:687-99.

2 Lundgren KD, Richtnér NG, Sjöstrand T. The Rönnskär disease. Nord Med 1951;46:1556-60. (In Swedish.)

3 Lundgren KD. Damages in the respiratory organs among workers at a smelter. Nordisk Hygienisk Tidskrift 1954;3:66-81. (In Swedish.)

4 Warfvinge LE. Contribution to the diagnostic of the Rönnskär bronchitis. Svenska Läkarhdningen 1965;65:1698-1701. (In Swedish.)

5 Holmqvist I. Occupational arsenical dermatitis. Acta Derm Venereol 1951;31:suppl 26.

6 Axelsson O, Dahlgren E, Jansson CD, Rehnlund O. Arsenic exposure and mortality: a case-referent study from a Swedish copper smelter. Br J Ind Med 1978;35:8-15.

7 Pershagen G, Elinder CG, Bolander AM. Mortality in a region surrounding an arsenic emitting plant. Environ Health 1977;19:133-7.

8 Pershagen G. Lung cancer mortality among men living near an arsenic emitting plant. Environ Health Perspect 1985;122: 684-94.

9 Wall S. Survival and mortality among Swedish smelter workers. Int J Epidemiol 1980;9:73-87.

10 Pershagen G, Wall A, Taube A, Linnman L. On the interaction between occupational exposure and smoking and its relationship to lung cancer. Scand J Work Environ Health 1981;7:302-9.

11 Wall S, Taube A. The Rönnskär case. An epidemiologic study of survival and mortality pattern among smelter workers. Basic document for the Swedish Cancer Committee. Ds S 1983;5: 1-181. (In Swedish.)

12 Nyström L, Rosén $M$, Wall $S$. Why are diabetes, stomach cancer and circulatory diseases more common in northern Sweden? Scand J Prim Health Care 1986;4:5-12.

13 Fox AJ, Collier PF. Low mortality rates in industrial cohort studies due to selection for work and survival in the industry. $\mathrm{Br}$ J Prev Soc Med 1976;30:225-30.

14 Nygren $\AA$. Historic working environment description-the Rönnskär smelter. Report of investigation 1980. Skelleftehamn: Boliden Metall AB, 1980. (In Swedish). 